\title{
Calcium-dependent mitochondrial cAMP production enhances aldosterone secretion
}

Dávid Katona ${ }^{\mathrm{a}}$, Anikó Rajki ${ }^{\mathrm{b}}$, Giulietta Di Benedetto ${ }^{\mathrm{c}, \mathrm{d}}$, Tullio Pozzan ${ }^{\mathrm{c}, \mathrm{d}}$, András Spät $\mathrm{t}^{*}$

${ }^{a}$ Department of Physiology, Semmelweis University Medical School, Budapest, Hungary

${ }^{b}$ Laboratory of Molecular Physiology, Hungarian Academy of Sciences, Budapest, Hungary

'Institute of Neuroscience, Italian National Research Council, Padova, Italy

${ }^{\mathrm{d}}$ Venetian Institute of Molecular Medicine, Padova, Italy

*Correspondanding author. Dept. of Physiology, Semmelweis University, P.O.Box 259, H-1444 Budapest, Hungary. Tel.: +36 14591500 ext. 60427, fax: +36 1266740.

E-mail address: spat@eok.sote.hu

Abbreviations: COX-IV, cytochrome $c$ oxidase IV; mt-cAMP, mitochondrial cAMP; 2-OHE, 2hydroxy-estradiol; sAC, soluble adenylyl cyclase 


\begin{abstract}
Glomerulosa cells secrete aldosterone in response to agonists coupled to $\mathrm{Ca}^{2+}$ increases such as angiotensin II and corticotrophin, coupled to a cAMP dependent pathway. A recently recognized interaction between $\mathrm{Ca}^{2+}$ and $\mathrm{cAMP}$ is the $\mathrm{Ca}^{2+}$ - induced cAMP formation in the mitochondrial matrix. Here we describe that soluble adenylyl cyclase (sAC) is expressed in H295R adrenocortical cells. Mitochondrial cAMP formation, monitored with a mitochondria-targeted fluorescent sensor $(4 \mathrm{mtH} 30)$, is enhanced by $\mathrm{HCO}_{3}{ }^{-}$and the $\mathrm{Ca}^{2+}$ mobilizing agonist angiotensin II. The effect of angiotensin II is inhibited by 2-OHE, an inhibitor of sAC, and by RNA interference of sAC, but enhanced by an inhibitor of phosphodiesterase PDE2A. Heterologous expression of the $\mathrm{Ca}^{2+}$ binding protein $\mathrm{S} 100 \mathrm{G}$ within the mitochondrial matrix attenuates angiotensin II-induced mitochondrial cAMP formation. Inhibition and knockdown of sAC significantly reduce angiotensin II - induced aldosterone production. These data provide the first evidence for a cell-specific functional role of mitochondrial cAMP.
\end{abstract}

\title{
1. Introduction
}

Cyclic AMP and $\mathrm{Ca}^{2+}$, the two most common second messengers in eukaryotic cells, control a variety of cellular functions as diverse as secretion, contraction, cell movement and death. These two messengers may act synergistically, as observed e.g. in cardiac myocytes, whereas their action may be antagonistic in other tissues, as in smooth muscle cells (Bolton et al., 1999; Schaub and Kunz, 1986; Sperelakis, 1990). In aldosterone-producing adrenal glomerulosa cells angiotensin II and extracellular $\mathrm{K}^{+}$concentration control aldosterone secretion via $\mathrm{Ca}^{2+}$ signaling 
whereas the action of corticotrophin (ACTH) is mediated by cAMP (Spät and Hunyady, 2004). Under acute stimulatory conditions the site of action is, in both cases, the Steroidogenic Acute Regulatory Protein (StAR) that facilitates the cholesterol transport to the cholesterol side chain cleaving enzyme (cytochrome $\mathrm{P} 450_{\mathrm{scc}}$ ), located on the inner mitochondrial membrane (reviewed in (Hattangady et al., 2011; Spät and Hunyady, 2004)). Calcium ions exert intramitochondrial action(s) as well. By activating mitochondrial dehydrogenases (McCormack et al., 1990), elevation of mitochondrial matrix $\left[\mathrm{Ca}^{2+}\right]$ enhances the formation of reduced pyridine nucleotides in rat (Pralong et al., 1992; Pralong et al., 1994) and human (Rohács et al., 1997; Spät et al., 2012) glomerulosa cells. This effect contributes to the enhancement of aldosterone secretion in cells from both species (Spät et al., 2012; Wiederkehr et al., 2011).

Although ACTH and angiotensin II act synergistically on aldosterone secretion (Spät and Hunyady, 2004), several laboratories reported that angiotensin II reduces basal and ACTHinduced cAMP production (Bell et al., 1981; Marie and Jard, 1983; Woodcock and Johnston, 1984; Begeot et al., 1987) (but see (Baukal et al., 1994; Burnay et al., 1998)). This inhibition has been attributed to the activation of the inhibitory G-protein, $G_{i}$ (Enyedi et al., 1986; Hausdorff et al., 1987; Lu et al., 1996; Maturana et al., 1999; Rocco et al., 1990). The recent discovery in cell lines and rat cardiac myocytes that agonist - induced mitochondrial $\mathrm{Ca}^{2+}$ signals can increase the production of cAMP and ATP within the mitochondrial matrix (Di Benedetto et al., 2013) may offer an explanation for this apparent paradox. Indeed an increase of cAMP in a small compartment, e.g. mitochondria (that represent $\sim 25 \%$ of the cytoplasmic volume in glomerulosa cells (Nussdorfer, 1980)), may be masked by the decrease of total intracellular cAMP caused by angiotensin II. Accordingly we decided to investigate whether mitochondrial cAMP, mt-cAMP, is modulated by angiotensin II-induced mitochondrial $\mathrm{Ca}^{2+}$ increases in adrenocortical cells and, 
more decisively, if mt-cAMP can influence the secretion of steroid hormones. Here we take advantage of a fluorescent cAMP sensor selectively targeted to the mitochondrial matrix (4mtH30) and show that in an adrenocortical cell line, H295R cells (Bird et al., 1993; Rainey et al., 1994), not only angiotensin II - induced $\mathrm{Ca}^{2+}$ release from the endoplasmic reticulum results in a significant increase of mt-cAMP formation, but also that the mt-cAMP increase contributes to hormone production.

\section{Materials and methods}

\subsection{Materials}

OPTI-MEM, Lipofectamine 2000, RNAiMax, Fluo-4 AM, Rhod-2 AM, SNARF AM and MitoTracker Deep Red were purchased from Life Technologies (Paisley, UK). siRNA for silencing sAC (MR2, (Di Benedetto et al., 2013)) and control siRNA (Universal Negative Control, SIC001) were obtained from Sigma-Aldrich (St. Louis, MO, USA). UltroSer G was from Bio Sepra (Cergy-Saint-Christophe, France). Coat-A-Count RIA kit was purchased from Siemens Health Care Diagnostic (Deerfield, IL).

S100G cDNA, fused to a mitochondrial targeting sequence and cloned into an adenovirus vector under the control of the tetON promoter (mitoS100G) was prepared by Dr. A. Wiederkehr (Geneva, Switzerland). H30 was from K. Jalink's lab (Ponsioen et al., 2004), 4mt-H30 and mtAlphi were constructed by the authors (G.D. \& T.P.) as described (Cano Abad et al., 2004; Di Benedetto et al., 2013).

Primary antibodies were purchased as follows: anti-soluble adenylyl cyclase (R21.002) was from CEP Biotech (Tamarac, FL), monoclonal anti- $\beta$-actin (A5316) was from Sigma-Aldrich, 
anti-COX IV (sc-69359) was from Santa Cruz (Dallas, TX). The secondary antibody (goat antimouse IgG horseradish peroxidase conjugate, R-05071-500) was purchased from Advansta (Menlo Park, CA). Other chemicals were obtained from Sigma-Aldrich.

\subsection{Cell culture and transfection}

H295R cells (CRL-2128, ATCC, Manassas, VA) were cultured in DMEM/Ham's F12 (1:1 $\mathrm{v} / \mathrm{v}$ ) containing $1 \% \mathrm{ITS}^{+}, 2 \%$ UltroSer G, $100 \mathrm{U} / \mathrm{ml}$ penicillin and $100 \mu \mathrm{g} / \mathrm{ml}$ streptomycin. One day before aldosterone experiments the concentration of Ultroser $\mathrm{G}$ was reduced to $0.5 \%$.

Cells $\left(2.5-4 * 10^{4} \mathrm{H} 295 \mathrm{R}\right)$ were plated onto $25-\mathrm{mm}$ diameter circular glass coverslips on day 1. For FRET experiments the cells were transfected on day 2 with $3 \mu \mathrm{g} 4 \mathrm{mtH} 30$ or $1.6 \mu \mathrm{g} \mathrm{H} 30$ DNA (per coverslip) using Lipofectamine 2000 in OPTI-MEM. FRET measurements were performed on day $5(4 \mathrm{mtH} 30)$ or day $4(\mathrm{H} 30)$. For silencing sAC, on day 3 the cells were transfected with 100 pmol MR2 siRNA or 100 pmol control RNA using lipofectamin RNAiMax in OPTI-MEM. The experiments were conducted on day 5. In Western blot studies cell lysis was performed 2 days after transfection with control or siRNA. For aldosterone measurements see subsection 2.7.

In order to increase the $\mathrm{Ca}^{2+}$ buffering capacity in the mitochondrial matrix $3 * 10^{4}$ cells were plated and infected 1 day later with Ad-mitoS100G (60 IFU/cell) together with $30 \mathrm{IFU} / \mathrm{cell}$ of Ad-tetON. Previous immunocytochemical examination using this protocol revealed the expression of S100G in $63 \%$ of the cells (Wiederkehr et al., 2011).

\subsection{Immunoblotting}


Cell lysis, SDS-PAGE and immunoblotting were performed as described (Fülöp et al., 2011) with the following modifications. Cell lysis was performed with protease-completed RIPA buffer. PMSF was used at a concentration of $1 \mathrm{mM} .10 \%$ SDS-PAGE was used.

\subsection{Confocal microscopy}

A Zeiss LSM710 confocal laser scanning microscope (operated with ZEN 11.0 software) and a $63 * / 1.3$ oil immersion objective (Plan-Apochromat, Zeiss) were used. Subcellular localisation of the cAMP sensors (H30 or 4mt-H30) was examined in cells preloaded with MitoTracker Deep Red. Applying multitrack mode the YFP component of the sensor was excited at $514 \mathrm{~nm}$, emitted light was measured between 520 and $595 \mathrm{~nm}$ whereas MTDR was excited at $633 \mathrm{~nm}$ and monitored at 640-740 $\mathrm{nm}$. The images were deconvoluted using ImageJ 1.6.0.

For monitoring cytosolic $\mathrm{Ca}^{2+}$ signals the cells were preloaded with Fluo-4, for recording mitochondrial $\mathrm{pH}$ changes the cells were transfected with mtAlphi. In both cases the applied excitation wavelength was $488 \mathrm{~nm}$, the emitted light was monitored between 500-550 nm. For monitoring cytosolic $\mathrm{pH}$ the cells were preloaded with SNARF AM, the dye was excited at 488 and the intensity of 612-699 nm emitted light was divided with that of the 560-600 nm light.

The optical slices were $4 \mu \mathrm{m}$ in the cytosolic measurements and $1.5 \mu \mathrm{m}$ in the mitochondrial ones, respectively. As exception, $\mathrm{H} 30$ localisation examinations 0.8 or $1 \mu \mathrm{m}$ optical slice was applied. Image acquisition frequency was $0.1 \mathrm{~Hz}$. In all kinetic studies performed with confocal microscopy fluorescence intensity was normalized to the average 60 -s intensity measured before stimulation $\left(\mathrm{F}_{\mathrm{o}}\right)$.

\subsection{Measurements with fluorescent wide-field microscopy}


cAMP level in the mitochondrial matrix and in the cytosol were monitored using 4mt-H30 and $\mathrm{H} 30$, respectively. These measurements as well as those of mitochondrial $\left[\mathrm{Ca}^{2+}\right]$ were performed on an inverted microscope (Axio Observer D1, Zeiss) equipped with a 40x1.4 PlanApochromat oil immersion objective (Zeiss) and a Cascade II camera (Photometrics). Excitation wavelengths were set by a random access monochromator connected to a xenon arc lamp (DeltaRAM, Photon Technology International). For ratiometric measurements of H30 or 4mtH30 excitation wavelength of $435 \mathrm{~nm}$ was selected along with a Dual-View emission splitting system (505dcxr, 480/30 and 535/30; Photometrics) enabling the acquisition of simultaneous donor (eCFP) and acceptor (eYFP) emission. The ratio 535/480 signals were evaluated with Metamorph Offline Version 7.7.0.0.

Since binding of cAMP to the sensor reduces FRET efficiency, an increase in cAMP concentration results in a decrease of $535 \mathrm{~nm}$ emission and an increase in $480 \mathrm{~nm}$ emission intensities. Accordingly, in order to express the cAMP increases vs time as an upward, rather than a downward deflection, the increase in cAMP level was computed as $100 *\left(\mathrm{R}_{\mathrm{o}}-\mathrm{R}\right) / \mathrm{R}_{\mathrm{o}}$ and expressed as $\Delta R / R_{0}(\%)$, where $R$ is the ratio of background-subtracted fluorescence intensities at $535 \mathrm{~nm}$ and $480 \mathrm{~nm}$ at any time in the experiment and $\mathrm{R}_{\mathrm{o}}$ the mean $535 / 480 \mathrm{~nm}$ ratio of the 100 $\mathrm{sec}$ period prior to stimulation. With regard to the often unstable baseline, the $4 \mathrm{mtH} 30$ signal was regarded as increased cAMP level if the integrated $\Delta R / R_{0}(\%)$ within at least a $100 \mathrm{sec}$ period during the 5 min post-stimulation period was significantly greater $(p<0.05)$ than that within a similar period preceding the stimulation.

Rhod-2 excitation wavelength was $550 \mathrm{~nm}$. The emitted light passed through a $570-\mathrm{nm}$ dichroic mirror and was measured with a 610/50 filter. The expressed fluorescence emission values $(\mathrm{F})$ were normalized to the mean $\mathrm{F}$ value of the 100 -sec period prior to stimulation. 


\subsection{Superfusion}

Microscopic experiments were carried at room temperature. Following a preincubation for 30 min (in the absence or presence of any inhibitor) the coverslips were superfused with a modified Krebs-Ringer solution containing $140 \mathrm{mM} \mathrm{Na}^{+}, 4.5 \mathrm{mM} \mathrm{K}^{+}, 1.2 \mathrm{mM} \mathrm{Ca}^{2+}, 0.5 \mathrm{mM} \mathrm{Mg}^{2+}, 5 \mathrm{mM}$ Hepes and $2 \mathrm{mM} \mathrm{HCO}_{3}{ }^{-}$(pH 7.4). The flow rate was $\sim 1 \mathrm{ml} / \mathrm{min}$. The solutions were applied with a solenoid valve-equipped, gravity-driven superfusion system, terminating at $\sim 2 \mathrm{~mm}$ from the selected cells.

\subsection{Aldosterone production}

Cells (150 - 300 thousand/well) were plated in a 24-well culture dish (day 1). On day 3 the UltroSer $G$ content of the culture medium was reduced to $0.1 \%$. On day 4 , after a 30 -min preincubation in serum-free medium that contained 2-OHE or solvent, the cells were incubated at $37^{\circ}$ for 2 hours in a similar medium, with or without angiotensin II. When the cells were transfected with control or siRNA on day 2 , UltroSer G content was reduced on day 4 and final incubation, as detailed above, took place in day 5.

Aldosterone and protein content of the supernatant were determined with Coat-A-Count RIA kit and Bradford assay, respectively.

\subsection{Statistics}

Means + S.E.M. are used. With the exception of cytosolic $\mathrm{pH}$ measurements all the experiments were performed on cells derived from at least two different cell passages. For 
estimating significance of differences, Student's unpaired $t$-test, sign test, chi-square test or factorial ANOVA was used, as appropriate. Data were analyzed with Statistica 9.

\section{Results}

\subsection{Expression of soluble adenylyl cyclase in H295R cells}

A specific antibody against sAC (Zippin et al., 2003) revealed an approximately $50 \mathrm{kDa}$ protein band in Western-blots of total lysates from both HeLa and H295R cells. When comparing samples of identical protein mass, the average density of the sAC band in H295R cells attained $60 \pm 9 \%$ of that in HeLa cells $(n=5)$. Two days after transfecting H295R cells with a specific siRNA (MR2, (Di Benedetto et al., 2013)) the density of the sAC band (related to that of $\beta$-actin) was $74 \pm 18 \%$ that of control siRNA-transfected cells (n=3, Fig. 1A). After permeabilizing the cells with digitonin $\left(25 \mu \mathrm{g} / \mathrm{ml}, 5 \mathrm{~min}, 4^{\circ} \mathrm{C}\right)$ the majority of immunoreactive sAC (related to the mitochondrial marker COX-IV) remained in the particulate fraction ( $\mathrm{n}=3$, data not shown). Altogether, these data are compatible with the conclusion that the majority of sAC in H295R cells, similarly to COS-1 cells (Acin-Perez et al., 2009b) is not cytosolic, but it is localized in membrane bound organelles, most likely the mitochondria .

\subsection{Mitochondrial cAMP as measured with 4mtH30 in H295R cells}

The cAMP sensor $4 \mathrm{mtH} 30$ consists of 4 copies of human COX VIII targeting sequence fused to the N-terminus of the cAMP sensor H30. The latter contains, between ECFP and EYFP, the 
whole Epac1 protein, rendered catalytically inactive with two mutations in the Rap1 binding domain and deprived of the membrane-targeting DEP domain (Ponsioen et al., 2004). Confocal microscopy revealed that in H295R cells, 3 days after transfection, $4 \mathrm{mtH} 30$ shows, as previously described in other cells, an excellent colocalization with the classical mitochondrial marker Mitotracker Deep Red (Pearson coefficient: $0.863 \pm 0.054$, n=6; Fig.1B).

Cyclic AMP binding to H30/4mtH30 reduces the efficiency of FRET between CFP and YFP, therefore elevation of cAMP concentration causes a decrease in the ratio, $\mathrm{R}$, between the fluorescence emitted at $535 \mathrm{~nm}$ (YFP) and that emitted at $480 \mathrm{~nm}$ (CFP), shown on Figures as $\Delta R / R_{0} \times 100 . R_{0}$ is the average $\mathrm{R}$ of a 100 s control interval. Superfusion with control medium for 450 seconds did not evoke any significant change in the FRET signal ( $n=25$, Fig. $2 B)$.

To test whether intramitochondrial cAMP level can be modulated by activation of matrix sAC, H295R cells transfected with 4mtH30, were superfused with an isosmotic medium containing $50 \mathrm{mM} \mathrm{HCO}_{3}{ }^{-}$(as sAC is known to be activated by bicarbonate ions (Buck et al., 1999; Jaiswal and Conti, 2003; Litvin et al., 2003; Steegborn et al., 2005b)). An increase in the $\Delta \mathrm{R} / \mathrm{R}_{0}$ was observed in $75 \%$ of the examined 20 cells (Fig. 2A). Noteworthy, in parallel, the measurement of matrix pH with mtAlphi (Cano Abad et al., 2004) revealed a net alkalinisation upon $\mathrm{HCO}_{3}{ }^{-}$addition ( $\mathrm{n}=20$, Fig. 2C). Given that $\mathrm{pH}$ alkalinization results in an increase of YFP fluorescence (Di Benedetto et al., 2013), the total rise of mt-cAMP may be underestimated.

The data presented in the section showed that the cAMP sensor $4 \mathrm{mtH} 30$ was appropriately targeted to the mitochondrial matrix (as previously described (Di Benedetto et al., 2013)) and responded in the expected way to bicarbonate, applied as positive control.

\subsection{Effect of angiotensin II on mitochondrial cAMP formation}


In preliminary experiments we examined the effect of 1 and $10 \mathrm{nM}$ angiotensin II on the level of mt-cAMP. The effect of $1 \mathrm{nM}$ was recorded in 133 cells. A cell was regarded responsive in terms of cAMP response if the integrated $\Delta \mathrm{R} / \mathrm{R}_{\ominus}$ value within at least a 100 -sec period during the 5 -min post-stimulation period was significantly greater $(\mathrm{p}<0.05)$ than that within a similar period preceding the stimulation. Elevation of mt-cAMP was observed in $40 \%$, whereas a small decrease of the mt-cAMP signal was detected in $6 \%$ of cases $(p<0.01)$.

In the next series of experiments we studied the effects of $10 \mathrm{nM}$ angiotensin II. First angiotensin - induced changes in cytosolic (Fluo-4) and mitochondrial (Rhod-2) $\left[\mathrm{Ca}^{2+}\right]$ were measured in the same cells. At the single cell level the cytosolic $\mathrm{Ca}^{2+}$ signals were variable in amplitude and kinetics, yet they were faithfully transferred to the mitochondrial matrix in all cells (Supplementary Fig. 1). Examining altogether 52 cells the peptide brought about a mt-cAMP elevation in $73 \%$ of the cells (these cells are termed responsive cell, see previous paragraph). In spite of the heterogeneity between individual responses (Supplementary Fig. 2), the averaged curve of responsive cells (Fig. 3A) convincingly displayed a mitochondrial response. The average $\Delta \mathrm{R} / \mathrm{R}_{\mathrm{o}}$ of a 100 -sec period (showing the highest cAMP signal) increased by $2.28 \pm 0.23 \%$ as compared with that of the 100 s pre-stimulation period $(n=34)$. (Due to a decreasing ratio during the control period the response could not be quantified in 4 cells). A negative response was observed in $8 \%$ (increase vs. decrease: $p<0.0001$, Fig. $3 \mathrm{C}$ ) and the not responding were the remaining $19 \%$ of the cells (Fig. 3B). Given that the percentage of responding cells in the $10 \mathrm{nM}$ angiotensin II group was significantly higher than in the $1 \mathrm{nM}$ group $(\mathrm{p}=0.0001)$, in subsequent experiments we focused on the effects of $10 \mathrm{nM}$ angiotensin II.

Considering the variability of cAMP rises in different cells and different preparations both in terms of amplitude and kinetics, a significant parameter to compare different conditions appeared 
to be the percentage of responsive cells. This parameter was, unless otherwise indicated, used in evaluating the following experiments. In order to inhibit sAC cells stimulated with $10 \mathrm{nM}$ angiotensin II, were exposed to the sAC inhibitor 2-OHE $(20 \mu \mathrm{M})$ (Steegborn et al., 2005a). The inhibitor was present also during a 30-min preincubation. Supplementary Fig. 3 demonstrates that the drug did not modify either the cytosolic or mitochondrial $\mathrm{Ca}^{2+}$ response to angiotensin II; however, at the same dose, it reduced the percentage of cells showing a mt-cAMP increase to angiotensin II by $34 \%(p=0.0135$, Fig. 4A). The specificity of the inhibitor was confirmed by transfecting the cells 2 days earlier with MR2, a specific siRNA for the sAC gene. In this case the percentage of responding cells decreased by $67 \%(p=0.006$, Fig. 4B). Di Benedetto et al. (2013) showed that a generic inhibitor of phosphodiesterases PDE, such as IBMX, or a PDE2A specific blocker, increase mt-cAMP level in response to stimulation. We thus examined the effect of the PDE2A inhibitor EHNA (erythro-9-(2-hydroxyl-3-nonyl)adenine (Acin-Perez et al., 2011)) on angiotensin II - induced changes in mt-cAMP. EHNA also added to the preincubating medium, evoked no significant change in the percentage of responsive cells, but the peak amplitude of the response was significantly higher in the presence of $10 \mu \mathrm{M}$ EHNA $(p=0.007$, Fig. 4D).

In order to confirm that angiotensin II - induced mt-cAMP response was induced by increased mitochondrial $\left[\mathrm{Ca}^{2+}\right]$, the peak increases in matrix $\mathrm{Ca}^{2+}$ were attenuated with heterologously expressed mitoS100G, a mitochondria-targeted $\mathrm{Ca}^{2+}$ binding protein under the control of doxycycline (DOX) - inducible tetOn promoter (Wiederkehr et al., 2011). We previously demonstrated that expression of mitoS $100 \mathrm{G}$ results in a significant reduction in the amplitude of the mitochondrial $\mathrm{Ca}^{2+}$ increases. In DOX-negative control cells 9 out of 14 cells showed an angiotensin II - induced mt-cAMP increase, whereas only 3 out of 12 cells showed a similar 
response after DOX-dependent infection. The difference between the two groups was significant $(p=0.045$, Fig. 4C).

The data in this section thus show that the mitochondrial sAC can be activated by angiotensin II in a concentration-dependent way. Pharmacological inhibition and silencing of sAC, as well as $\mathrm{Ca}^{2+}$ buffering in the mitochondrial matrix, reduce the effect of angiotensin II whereas inhibition of the mitochondrial cAMP phosphodiesterase enhances the angiotensin-induced rise of mtcAMP.

\subsection{Role of mitochondrial cAMP in the control of aldosterone production}

We next investigated whether mt-cAMP plays any role in steroid hormone secretion, the specific function of adrenocortical cells. H295R cells were exposed for 2 hours to angiotensin II, applied at maximal $(1 \mathrm{nM})$ or supramaximal concentration $(10 \mathrm{nM})$ and their aldosterone production was measured. Angiotensin II evoked a mean 2.7 fold increase in aldosterone secretion whereas the increase in 2-OHE treated cells was reduced to 1.5 fold on average (Fig. 5A). Statistical analysis after pooling the 1 and $10 \mathrm{nM}$ data showed that the effect of 2-OHE was highly significant $\left(p=1 \times 10^{-6}\right)$ and, more importantly, the negative interaction of the agonist and the enzyme inhibitor was also highly significant $\left(p=1 \times 10^{-6}\right)$.

The observation obtained with pharmacological inhibition of sAC has been confirmed by transfection with siRNA. The 2-hour hormone production was examined 3 days after transfection with 0. As shown in Fig. 5B aldosterone secretion in siRNA-transfected cells was significantly smaller than in control RNA-transfected cells $(\mathrm{p}=0.002)$ and, more importantly, the extent of stimulation was reduced from an average of 1.61 to 1.47 , reflecting a significant negative interaction of gene silencing with the agonist $(p=0.041)$. 
sAc is localized both in the cytosol (Braun and Dods, 1975; Jaiswal and Conti, 2001) and in the mitochondrial matrix (Acin-Perez et al., 2009a). The question then arises as to whether the effects of sAC inhibition on aldosterone production depends on mt-sAC or cytosolic sAC or both. In order to distinguish among these possibilities cells were transfected with $\mathrm{H} 30$, the cytosolic version of the cAMP sensor. The probe, as expected, was selectively localized in the cytosol and excluded from mitochondria (Fig. 6A and B). $10 \mathrm{nM}$ angiotensin II induced a clear cytosolic cAMP rise in 16 out of 22 cells (Fig. 6C) in controls, the average $\Delta R / R_{0}$ of a 100 -sec stimulation period in the responding control cells showed a $3.93 \pm 0.45 \%$ increase. The sAC inhibitor $2-$ OHE failed to influence this cytosolic cAMP response: $75 \%$ of 2-OHE-treated cells responded to angiotensin with cAMP signal, the average $\Delta R / R_{0}$ showed a $3.85 \pm 0.35 \%$ increase (Fig. $6 D$ ).

This observation demonstrates that angiotensin II is capable of increasing cytosolic cAMP level by activating a 2-OHE insensitive AC. In addition, superfusion with $50 \mathrm{mM}$ bicarbonate (that induces an increase in mt-cAMP) is associated with a drop in $\Delta \mathrm{R} / \mathrm{R}_{\mathrm{o}}$ in the cytosol in $75 \%$ of the cells $(\mathrm{n}=16$, Fig. $6 \mathrm{E})$. This drop is probably only apparent as bicarbonate induces an alkalinization of cytosolic $\mathrm{pH}$, similar in amplitude to that caused in the mitochondrial matrix (not shown). We thus conclude that in H295R cells: i) the activity of sAC in the cytosol is negligible and ii) inhibition of angiotensin II-induced aldosterone production by 2-OHE depends on its inhibition of mitochondrial sAC.

Summarizing the data in this section, basal and angiotensin II-stimulated aldosterone secretion was reduced by inhibiting or silencing sAC. The activity of sAC in the cytosol is negligible, but the cytosolic $\mathrm{Ca}^{2+}$ increase elicited by angiotensin II can activate transmembrane adenylyl cyclase(s).

\section{Discussion}


The recent discovery of the existence of an autonomous intramitochondrial cAMP signaling machinery (composed by a sAC isoform and a cAMP degrading mechanism sensitive to both IBMX and EHNA, a PDE2 specific inhibitor (Acin-Perez et al., 2009b)) has been followed by the direct demonstration that in HeLa and CHO cells as well as in rat cardiomyocytes a rise in cAMP can be triggered by an increase in $\mathrm{HCO}_{3}^{-}$and $\mathrm{Ca}^{2+}$ in the matrix, acting synergically (Di Benedetto et al., 2013). Intramitochondrial cAMP rise is paralleled by a significant increase of the matrix level of ATP. On the contrary, no consensus exists as to the target(s) of cAMP in the mitochondrial matrix (see for example (Acin-Perez et al., 2009b; Di Benedetto et al., 2013; Lefkimmiatis et al., 2013)). Moreover, and most importantly, the possible functional effects of this cAMP increase are still largely unexplored.

In the present paper we have investigated whether the matrix cAMP signaling toolkit is expressed also in other differentiated cell types and whether functions other than ATP production can be modulated by the cAMP concentration in the matrix. To this end we used an adrenocortical cell line, H295R cells, a model system widely employed to investigate the function of glomerulosa cell, especially the agonist dependent production of aldosterone (Bird et al., 1993; Rainey et al., 1994). For estimating mt-cAMP formation we employed the FRET-based sensor 4mtH30 (Di Benedetto et al., 2013). This sensor, as other probes of the same family, undergoes a change (reduction) of FRET upon increases in the local cAMP level. However other factors, e.g., differential photobleaching of CFP and YFP fluorescence or $\mathrm{pH}$ changes may lead to apparent, artifactual, changes in mt-cAMP. These problems were directly addressed in the present experiments and in the study of Di Benedetto et al. (2013). In particular, as far as photobleaching is concerned, superfusion with control medium for $450 \mathrm{~s}$ (the maximal duration of the treatments with drugs or agonists) failed to exert any significant influence on the FRET signal. As to $\mathrm{pH}$ 
effects, neither 2-OHE or EHNA cause any change of matrix pH (Di Benedetto et al., 2013). Last, but not least, all the treatments used (sAC inhibitor 2-OHE, siRNA against $s A C$ or the phosphodiesterase inhibitor EHNA) modified mt-cAMP in the expected direction, giving concordant results. More specifically, we here demonstrate that: i) angiotensin II, an agonist known to induce (often oscillatory) increases in cytosolic and mitochondrial $\mathrm{Ca}^{2+}$ (Brandenburger et al., 1996; Lalevee et al., 2003; Spät and Hunyady, 2004; Spät and Pitter, 2004), as well as reduction in pyridine nucleotides (Pralong et al., 1992; Pralong et al., 1994; Rohács et al., 1997), also causes a dose dependent rise in mt-cAMP; ii) the effects of angiotensin II on mt-cAMP are reduced by buffering matrix $\mathrm{Ca}^{2+}$ increases caused by the expression of mitoS100G (Wiederkehr et al., 2011), by siRNA reduction in sAC expression or by the sAC inhibitor 2-OHE and are augmented by the PDE2A inhibitor EHNA; iii) a clear increase in mt-cAMP is also caused by the well known sAC activator, bicarbonate (Buck et al., 1999; Jaiswal and Conti, 2003; Litvin et al., 2003; Steegborn et al., 2005b). Three lines of evidence support the conclusion that sAC is primarily localized in the mitochondria: i) the majority of the protein band (molecular weight $\cong 50$ $\mathrm{kDa}$ ), revealed in lysates of $\mathrm{H} 295 \mathrm{R}$ cells by immunoblotting with anti-sAC antibodies and corresponding to the truncated, fully active form of sAC (Buck et al., 1999), remained in the pellet after plasma membrane permeabilization with digitonin; ii) the mitochondrial cAMP sensor 4mtH30 and the cytosolic sensor H30 responded with opposite signals to bicarbonate addition, i.e. a rise with $4 \mathrm{mtH} 30$ and a small drop with $\mathrm{H} 30$, though bicarbonate caused an alkalinization in both compartments; iii) the sAC inhibitor 2-OHE added together with angiotensin II, attenuated the mt-cAMP signal, but had no effect on the cytosolic cAMP rise caused by the stimulus.

The final key question concerns the functional significance of the mt-cAMP formation. In order to address this point we investigated the effect of manipulating mt-cAMP on the primary 
biological function of adrenocortical cells, namely hormone production. The stimulation of aldosterone production by the cAMP rise induced by ACTH addition and the role of angiotensin II (or $\mathrm{K}^{+}$) dependent rise in cytosolic $\mathrm{Ca}^{2+}$ on hormone production (and the potentiation of cytosolic $\mathrm{Ca}^{2+}$ - evoked aldosterone production (Wiederkehr et al., 2011) by mitochondrial $\mathrm{Ca}^{2+}$ rises) are firmly established facts. On the contrary, the crosstalk between the $\mathrm{Ca}^{2+}$ and cAMP signaling systems has been thoroughly investigated in the past, but conflicting results have been reported. The Tait group showed a $\mathrm{K}^{+}$-evoked increase in cAMP formation in rat glomerulosa cells (Hyatt et al., 1986). Several years later, the $\mathrm{Ca}^{2+}$-activatable isoform 1 of adenylyl cyclase (AC1) was shown to be expressed in human glomerulosa and fasciculata cells (Cote et al., 2001) whereas another isoform (AC3), possibly also activated by $\mathrm{Ca}^{2+}$, was found in human (Cote et al., 2001), rat (Nishimoto et al., 2013) and bovine (Burnay et al., 1998) glomerulosa cells. On the contrary, a reduced cAMP formation was reported in angiotensin II - stimulated rat glomerulosa (Bell et al., 1981; Woodcock and Johnston, 1984) or bovine adrenocortical cells (Begeot et al., 1988; Marie and Jard, 1983). In our hands, in H295R cells, angiotensin II caused a clear and reproducible increase in cytosolic cAMP. Whether this rise of cAMP depends on $\mathrm{Ca}^{2+}$ dependent activation of $\mathrm{AC}$ remains to be established. It is not easy to reconcile these apparently contradictory findings. It may be proposed that coexpression of different amounts of $\mathrm{Ca}^{2+}$ activated and $\mathrm{Ca}^{2+}$-inhibited isoforms (AC5 and AC6, (human: (Cote et al., 2001), rat: (Shen et al., 1997)) is a species (or cell) specific feature and may account for the different results obtained in different models. Despite these contradictions on the relationships between angiotensin II stimulation and cAMP levels, a consensus exists on the synergic actions of cytosolic cAMP produced by ACTH and $\mathrm{Ca}^{2+}$ rises on aldosterone production (Spät and Hunyady, 2004).

The evidence presented here, i.e. a reduction in hormone secretion in angiotensin II stimulated cells by conditions that reduce the rise in mt-cAMP levels without affecting cytosolic $\mathrm{Ca}^{2+}$, 
suggests that, similarly to what occurring for the cysosolic compartment, the mt-cAMP rise synergizes with intramitochondrial $\mathrm{Ca}^{2+}$ in regulating aldosterone biosynthesis. The specific molecular target of mt-cAMP, however, remains to be established (Lefkimmiatis et al., 2013).

Summarizing the present observations, in addition to a possible activation of a transmembrane $\mathrm{AC}$ by the cytosolic $\mathrm{Ca}^{2+}$ signal, also a mitochondrial $\mathrm{AC}$, the soluble $\mathrm{sAC}$, is activated by mitochondrial $\mathrm{Ca}^{2+}$ increases. Activation of sAC and thus of mt-cAMP, enhances the $\mathrm{Ca}^{2+}$ - induced production of aldosterone, a hormone controlling not only salt-water balance, but also playing a significant role in the control of blood pressure and in the progress of various cardiovascular, renal and inflammatory diseases (Andersen, 2013; Briet and Schiffrin, 2010; Gomez-Sanchez, 2014; Tomaschitz et al., 2010). These data provide the first evidence that cAMP rise in mitochondria has not only a general bioenergetics function (stimulation of ATP production (Acin-Perez et al., 2009b; Di Benedetto et al., 2013)), but also a cell specific role, such as the production of the glomerulosa cell hormone, aldosterone.

\section{Authors' contribution}

A.S. designed the experiment and wrote the manuscript. A.S. and D.K. performed the microscopic examinations, off-line evaluations and statistical calculations. A.R. performed cellular and analytical works. G. D. B. and T. P. designed and prepared 4mtH30, and contributed with critical remarks and advice to the whole work.

\section{Acknowledgements}


The present study was supported by the Hungarian Academy of Sciences, the Italian Institute of Technology (IIT, Seed Project), the Italian Ministry of Education (FIRB RBAP11X42L projects), the CARIPARO Foundation (mitochondrial $\mathrm{Ca}^{2+}$ uptake and cardiac pathophysiology) and the CNR special project "Aging”. We thank Dr. A. Wiederkehr (Geneva) for Ad-mitoS100G. We acknowledge the methodological advice of Prof. P. Várnai and Dr. G. Sirokmány (Budapest).

\section{Appendix. Supplementary material}

Supplemental data associated with this article can be found, in the online version at ..... 


\section{References}

Acin-Perez, R., Russwurm, M., Gunnewig, K., Gertz, M., Zoidl, G., Ramos, L., Buck, J., Levin, L.R., Rassow, J., Manfredi, G., Steegborn, C., 2011. A phosphodiesterase 2A isoform localized to mitochondria regulates respiration. J Biol Chem 286, 30423-30432.

Acin-Perez,R.; Salazar,E.; Brosel,S.; Yang,H.; Schon,E.A.; Manfredi,G., 2009a. Modulation of mitochondrial protein phosphorylation by soluble adenylyl cyclase ameliorates cytochrome oxidase defects. EMBO Mol.Med. 1, 392-406

Acin-Perez, R., Salazar, E., Kamenetsky, M., Buck, J., Levin, L.R., Manfredi, G., 2009b. Cyclic AMP produced inside mitochondria regulates oxidative phosphorylation. Cell Metab 9, 265276.

Andersen, K., 2013. Aldosterone synthase inhibition in hypertension. Curr. Hypertens. Rep. 15, 484-488.

Baukal, A.J., Hunyady, L., Catt, K.J., Balla, T., 1994. Evidence for participation of calcineurin in potentiation of agonist-stimulated cyclic AMP formation by the calcium- mobilizing hormone,angiotensin II. J. Biol. Chem. 269, 24546-24549.

Begeot, M., Langlois, D., Penhoat, A., Saez, J.M., 1988. Variations in guanine-binding proteins (Gs, Gi) in cultured bovine adrenal cells. Consequences on the effects of phorbol ester and angiotensin II on adrenocorticotropin-induced and cholera-toxin-induced cAMP production. Eur. J. Biochem. 174, 317-321.

Bell, J.B.G., Tait, J.F., Tait, S.A.S., Barnes, G.D., Brown, B.L., 1981. Lack of effect of angiotensin on levels of cyclic AMP in isolated adrenal zona glomerulosa cells from the rat. J. Endocrinol. 91, 145-154.

Bird, I.M., Hanley, N.A., Word, R.A., Mathis, J.M., McCarthy, J.L., Mason, J.I., Rainey, W.E., 1993. Human NCI-H295 adrenocortical carcinoma cells: A model for angiotensin-IIresponsive aldosterone secretion. Endocrinology 133, 1555-1561.

Bolton, T.B., Prestwich, S.A., Zholos, A.V., Gordienko, D.V., 1999. Excitation-contraction coupling in gastrointestinal and other smooth muscles. Annu. Rev. Physiol 61, 85-115.

Brandenburger, Y., Kennedy, E.D., Python, C.P., Rossier, M.F., Vallotton, M.B., Wollheim, C.B., Capponi, A.M., 1996. Possible role for mitochondrial calcium in angiotensin II- and potassium-stimulated steroidogenesis in bovine adrenal glomerulosa cells. Endocrinology $137,5544-5551$.

Braun, T., Dods, R.F., 1975. Development of a Mn-2+-sensitive, "soluble" adenylate cyclase in rat testis. Proc. Natl. Acad. Sci. U. S. A 72, 1097-1101.

Briet, M., Schiffrin, E.L., 2010. Aldosterone: effects on the kidney and cardiovascular system. Nat. Rev. Nephrol. 6, 261-273. 
Buck, J., Sinclair, M.L., Schapal, L., Cann, M.J., Levin, L.R., 1999. Cytosolic adenylyl cyclase defines a unique signaling molecule in mammals. Proc. Natl. Acad. Sci U. S. A 96, 79-84.

Burnay, M.M., Vallotton, M.B., Capponi, A.M., Rossier, M.F., 1998. Angiotensin II potentiates adrenocorticotrophic hormone- induced cAMP formation in bovine adrenal glomerulosa cells through a capacitative calcium influx. Biochem. J. 330, 21-27.

Cano Abad, M.F., Di Benedetto, G., Magalhaes, P.J., Filippin, L., Pozzan, T., 2004. Mitochondrial $\mathrm{pH}$ monitored by a new engineered green fluorescent protein mutant. J Biol Chem. 279, 11521-11529.

Cote, M., Guillon, G., Payet, M.D., Gallo-Payet, N., 2001. Expression and regulation of adenylyl cyclase isoforms in the human adrenal gland. J. Clin. Endocrinol. Metab 86, 4495-4503.

Di Benedetto, G., Scalzotto, E., Mongillo, M., Pozzan, T., 2013. Mitochondrial $\mathrm{Ca}^{2+}$ Uptake Induces Cyclic AMP Generation in the Matrix and Modulates Organelle ATP Levels. Cell Metab 17, 965-975.

Enyedi, P., Mucsi, I., Hunyady, L., Catt, K.J., Spät, A., 1986. The role of guanyl nucleotide binding proteins in the formation of inositol phosphates in adrenal glomerulosa cells. Biochem. Biophys. Res. Commun. 140, 941-947.

Fülöp, L., Szanda, G., Enyedi, B., Várnai, P., Spät, A., 2011. The effect of OPA1 on mitochondrial $\mathrm{Ca}^{2+}$ signaling. PLoS. One. 6, e25199.

Gomez-Sanchez, C.E., 2014. Non renal effects of aldosterone. Steroids 91, 1-2.

Hattangady, N.G., Olala, L.O., Bollag, W.B., Rainey, W.E., 2011. Acute and chronic regulation of aldosterone production. Mol. Cell Endocrinol.

Hausdorff, W.P., Sekura, R.D., Aguilera, G., Catt, K.J., 1987. Control of aldosterone production by angiotensin II is mediated by two guanine nucleotide regulatory proteins. Endocrinology $120,1668-1678$.

Hyatt, P.J., Tait, J.F., Tait, S.A.S., 1986. The mechanism of the effect of $\mathrm{K}^{+}$on the steroidogenesis of rat zona glomerulosa cells of the adrenal cortex: role of cyclic AMP. Proc. R. Soc. Lond. [Biol. ] 227, 21-42.

Jaiswal, B.S., Conti, M., 2001. Identification and functional analysis of splice variants of the germ cell soluble adenylyl cyclase. J Biol Chem 276, 31698-31708.

Jaiswal, B.S., Conti, M., 2003. Calcium regulation of the soluble adenylyl cyclase expressed in mammalian spermatozoa. Proc. Natl. Acad. Sci U. S. A 100, 10676-10681.

Lalevee, N., Resin, V., Arnaudeau, S., Demaurex, N., Rossier, M.F., 2003. Intracellular transport of calcium from plasma membrane to mitochondria in adrenal H295R cells: implication for steroidogenesis. Endocrinology 144, 4575-4585. 
Lefkimmiatis, K., Leronni, D., Hofer, A.M., 2013. The inner and outer compartments of mitochondria are sites of distinct cAMP/PKA signaling dynamics. J Cell Biol 202, 453-462.

Litvin, T.N., Kamenetsky, M., Zarifyan, A., Buck, J., Levin, L.R., 2003. Kinetic properties of "soluble" adenylyl cyclase. Synergism between calcium and bicarbonate. J Biol Chem 278, 15922-15926.

Lu, H.K., Fern, R.J., Luthin, D., Linden, J., Liu, L.P., Cohen, C.J., Barrett, P.Q., 1996. Angiotensin II stimulates T-type $\mathrm{Ca}^{2+}$ channel currents via activation of a $\mathrm{G}$ protein, $\mathrm{G}_{\mathrm{i}}$. Am. J. Physiol. Cell Physiol. 271, C1340-C1349.

Marie, J., Jard, S., 1983. Angiotensin II inhibits adenylate cyclase from adrenal cortex glomerulosa zone. FEBS Lett. 159, 97-101.

Maturana, A.D., Casal, A.J., Demaurex, N., Vallotton, M.B., Capponi, A.M., Rossier, M.F., 1999. Angiotensin II negatively modulates L-type calcium channels through a pertussis toxin-sensitive G protein in adrenal glomerulosa cells. J. Biol. Chem. 274, 19943-19948.

McCormack, J.G., Halestrap, A.P., Denton, R.M., 1990. Role of calcium ions in regulation of mammalian intramitochondrial metabolism. Physiol. Rev. 70, 391-425.

Nishimoto, K., Rainey, W.E., Bollag, W.B., Seki, T., 2013. Lessons from the gene expression pattern of the rat zona glomerulosa. Mol. Cell Endocrinol. 371, 107-113.

Nussdorfer, G.G., 1980. Cytophysiology of the adrenal zona glomerulosa. Int. Rev. Cytol. 64, 307-368.

Ponsioen, B., Zhao, J., Riedl, J., Zwartkruis, F., van der Krogt, G., Zaccolo, M., Moolenaar, W.H., Bos, J.L., Jalink, K., 2004. Detecting cAMP-induced Epac activation by fluorescence resonance energy transfer: Epac as a novel cAMP indicator. EMBO Rep. 5, 1176-1180.

Pralong, W.F., Hunyady, L., Várnai, P., Wollheim, C.B., Spät, A., 1992. Pyridine nucleotide redox state parallels production of aldosterone in potassium-stimulated adrenal glomerulosa cells. Proc. Natl. Acad. Sci. USA 89, 132-136.

Pralong, W.F., Spät, A., Wollheim, C.B., 1994. Dynamic pacing of cell metabolism by intracellular $\mathrm{Ca}^{2+}$. J. Biol. Chem. 269, 27310-27314.

Rainey, W.E., Bird, I.M., Mason, J.I., 1994. The NCI-H295 cell line: a pluripotent model for human adrenocortical studies. Mol. Cell Endocrinol. 100, 45-50.

Rocco, S., Ambroz, C., Aguilera, G., 1990. Interaction between serotonin and other regulators of aldosterone secretion in rat adrenal glomerulosa cells. Endocrinology 127, 3103-3110.

Rohács, T., Nagy, G., Spät, A., 1997. Cytoplasmic $\mathrm{Ca}^{2+}$ signalling and reduction of mitochondrial pyridine nucleotides in adrenal glomerulosa cells in response to $\mathrm{K}^{+}$, angiotensin II and vasopressin. Biochem. J. 322, 785-792. 
Schaub, M.C., Kunz, B., 1986. Regulation of contraction in cardiac and smooth muscles. J. Cardiovasc. Pharmacol. 8 Suppl 8, S117-S123.

Shen, T., Suzuki, Y., Poyard, M., Best-Belpomme, M., Defer, N., Hanoune, J., 1997. Localization and differential expression of adenylyl cyclase messenger ribonucleic acids in rat adrenal gland determined by in situ hybridization. Endocrinology 138, 4591-4598.

Spät, A., Fülöp, L., Szanda, G., 2012. The role of mitochondrial $\mathrm{Ca}^{2+}$ and NAD(P)H in the control of aldosterone secretion. Cell Calcium 52, 64-72.

Spät, A., Hunyady, L., 2004. Control of aldosterone secretion: a model for convergence in cellular signaling pathways. Physiol. Rev. 84, 489-539.

Spät, A., Pitter, J.G., 2004. The effect of cytoplasmic $\mathrm{Ca}^{2+}$ signal on the redox state of mitochondrial pyridine nucleotides . Molec. cell. Endocrin. 215, 115-118.

Sperelakis, N., 1990. Properties of calcium channels in cardiac muscle and vascular smooth muscle. Mol. Cell Biochem. 99, 97-109.

Steegborn, C., Litvin, T.N., Hess, K.C., Capper, A.B., Taussig, R., Buck, J., Levin, L.R., Wu, H., 2005a. A novel mechanism for adenylyl cyclase inhibition from the crystal structure of its complex with catechol estrogen. J Biol Chem 280, 31754-31759.

Steegborn, C., Litvin, T.N., Levin, L.R., Buck, J., Wu, H., 2005b. Bicarbonate activation of adenylyl cyclase via promotion of catalytic active site closure and metal recruitment. Nat. Struct. Mol. Biol 12, 32-37.

Tomaschitz, A., Pilz, S., Ritz, E., Obermayer-Pietsch, B., Pieber, T.R., 2010. Aldosterone and arterial hypertension. Nat. Rev. Endocrinol. 6, 83-93.

Wiederkehr, A., Szanda, G., Akhmedov, D., Mataki, C., Heizmann, C.W., Schoonjans, K., Pozzan, T., Spät, A., Wollheim, C.B., 2011. Mitochondrial matrix calcium is an activating signal for hormone secretion. Cell Metab 13, 601-611.

Woodcock, E.A., Johnston, C.I., 1984. Inhibition of adenylate cyclase in rat adrenal glomerulosa cells by angiotensin II. Endocrinology 115, 337-341.

Zippin, J.H., Chen, Y., Nahirney, P., Kamenetsky, M., Wuttke, M.S., Fischman, D.A., Levin, L.R., Buck, J., 2003. Compartmentalization of bicarbonate-sensitive adenylyl cyclase in distinct signaling microdomains. FASEB J 17, 82-84. 


\section{Legend of Figures}

Fig. 1 Expression of soluble adenylyl cyclase and its sensor 4mt-H30 in mitochondria of H295 cells. (A) Representative Western blot of sAC expression in H295R cells, transfected with control siRNA or siRNA for sAC (MR2). $\beta$-actin was used as loading control. HeLa cells served as positive control for SAC. For comparing expression in the two cell types protein content of the samples is indicated above the lanes. (B) Mitochondrial localisation of 4mt-H30 in an H295R cell. Cells were transfected with $4 \mathrm{mt}-\mathrm{H} 30$ (shown in green) three days earlier and loaded with MitoTracker Deep Red (MTDR, shown in red) before the confocal microscopy. Colocalisation is indicated in the merged image (left bottom) in yellow. The optical slice was $1.5 \mu \mathrm{m}$. The result of line scanning in the merged image is shown in the right bottom panel.

Fig. 2 Effect of bicarbonate on mitochondrial cAMP formation. (A) Effect of superfusion with $50 \mathrm{mM}$ bicarbonate on mt-cAMP was recorded with $4 \mathrm{mt}-\mathrm{H} 30$. Out of 20 examined cells the averaged response curve is shown for 16 cells in which the integrated fluorescence intensity within at least a 100 -sec period during the 5 -min post-stimulation period was significantly greater $(\mathrm{p}<0.05)$ than within a similar period preceding the stimulation. The increase in cAMP was computed as $100 *\left(\mathrm{R}_{\mathrm{o}}-\mathrm{R}\right) / \mathrm{R}_{\mathrm{o}}$ and expressed as $\Delta \mathrm{R} / \mathrm{Ro}(\%)$ where $\mathrm{R}$ was the ratio of fluorescence intensity of raw FRET (emission at $535 \mathrm{~nm}$ ) and eCFP $(480 \mathrm{~nm}), \mathrm{R}_{\mathrm{o}}$ was the mean ratio of the $100-\mathrm{sec}$ period prior to stimulation. Means \pm are shown. (B) Superfusion with control medium does not induce any significant change in the mitochondrial cAMP level. Averaged curve for 25 cells, superfused for 450 seconds. Means \pm S.E.M. are shown. (C) Effect of bicarbonate $(50 \mathrm{mM})$ and subsequent acetate $(30 \mathrm{mM})$ superfusion on mitochondrial $\mathrm{pH}$, monitored with mtAlphi. Upward deflection indicates increased $\mathrm{pH}$.

Fig. 3 Effect of superfusion with $10 \mathrm{nM}$ angiotensin II on mitochondrial cAMP formation as recorded with $4 \mathrm{mt}-\mathrm{H} 30$. The effect of the peptide was examined in 52 cells. (A) Averaged response curve is shown for 34 responsive cells in which the integrated fluorescence intensity within at least a 100 -sec period during the 5 -min post-stimulation period was significantly greater $(\mathrm{p}<0.05)$ than within a similar period preceding the stimulation. (Due to a decreasing ratio during the control period no response could be calculated in 4 further cells.) (B) Averaged curve of the mt-cAMP signal of 10 non-responsive cells. (C) Averaged curve of the mt-cAMP signal of 4 cells showing inverse signal. Means \pm are shown.

Fig. 4 Modification of angiotensin II - induced mitochondrial cAMP formation. The cells were (A) exposed to $20 \mu \mathrm{M}$ 2-OH-estradiol (2-OHE), (B) with control siRNA or MR2, a specific siRNA for $\mathrm{sAC},(\mathrm{C})$ infected with mitoS100G, a mitochondria-targeted $\mathrm{Ca}^{2+}$ binding protein or (D) exposed to $10 \mu \mathrm{M}$ EHNA, an inhibitor of the mitochondrial phosphodiesterase PDE2A. Percentage of cells displaying increased cAMP formation (red), no change (green) or reverse response (blue) is shown. In panels A, B and C the number of cells is shown within the columns. Peak amplitude (means + S.E.M.) of mt-cAMP-response in control or EHNA-treated cells is 
shown in panel D (number of cells is shown within the columns). The following significances were calculated: (A) 2-OHE: $\mathrm{p}=0.0135$, (B) MR2: $\mathrm{p}=0.006$, (C) mitoS100G: $\mathrm{p}=0.045$, (D) EHNA: $p=0.007$.

Fig. 5 Reduced activity of sAC and aldosterone secretion. (A) Effect of $20 \mu \mathrm{M} 2$-OHE on angiotensin II (1 or $10 \mathrm{nM})$ - induced aldosterone production. The effect of 2-OHE on hormone production as well as the negative interaction between the agonist and the enzyme inhibitor were significant $\left(p=1 \times 10^{-6}\right)$. (B) Effect of siRNA (MR2) against $\mathrm{sAC}$ on aldosterone secretion stimulated with $10 \mathrm{nM}$ angiotensin II. Examination of aldosterone secretion was performed 3 days after gene silencing. Both the reduction of hormone secretion by siRNA $(p=0.002)$ and the negative interaction between angiotensin II and siRNA were significant $(p=0,041)$. (Significance was estimated with factorial ANOVA.)

Fig. 6 Effect of angiotensin II (10 nM) on cAMP formation in cytosol. (A) Location of cytosolic cAMP sensor H30 was examined with confocal microscopy 2 days after transfection. Image in the YFP channel is shown. The optical layer was $0.8 \mu \mathrm{m}$. The arrows show H30-free mitochondria. (B) The merged image of the YFP channel (panel A) and the MitoTracker Deep Red (MTDR) channel is shown. Colocalization of H30 and MTDR would appear in yellow. (C) Angiotensin II (10 nM) - induced cytosolic cAMP formation. Representative for 16 (out of 22) cells. (D) Angiotensin II - induced cytosolic cAMP formation in the presence of $20 \mu \mathrm{M} 2$-OHE. Representative for 12 (out of 16) cells. (E) Effect of bicarbonate $(50 \mathrm{mM})$ superfusion on apparent cAMP level, measured with H30 Representative for 7 cells. 
Supplementary Fig. 1 Heterogeneity of angiotensin II - induced $\mathrm{Ca}^{2+}$ signalling. H295R cells were superfused with $10 \mathrm{nM}$ angiotensin II. Cytosolic and mitochondrial $\left[\mathrm{Ca}^{2+}\right]$, recorded with Fluo-4 and Rhod-2, respectively, are shown in three separate cells, representating 18 cells. Fluorescence intensity values $(\mathrm{F})$ were normalized to the control period values $\left(\mathrm{F}_{\mathrm{o}}\right)$.

Supplementary Fig. 2 Heterogeneity of the mitochondrial cAMP response to angiotensin II. The response to $10 \mathrm{nM}$ angiotensin II, recorded with $4 \mathrm{mt}-\mathrm{H} 30$, is shown in three separate cells. The increase in cAMP was computed as $100 *\left(\mathrm{R}_{\mathrm{o}}-\mathrm{R}\right) / \mathrm{R}_{\mathrm{o}}$ and expressed as $\Delta \mathrm{R} / \mathrm{Ro}(\%)$ where $\mathrm{R}$ was the ratio of fluorescence intensity of raw FRET (emission at $535 \mathrm{~nm})$ and eCFP $(480 \mathrm{~nm}), \mathrm{R}_{\mathrm{o}}$ was the mean ratio of the 100 -sec period prior to stimulation.

Supplementary Fig. 3 Effect of the sAC inhibitor drug 2-OH-estradiol (2-OHE, $20 \mu \mathrm{M})$ on angiotensin II (10 nM) - induced cytosolic and mitochondrial $\mathrm{Ca}^{2+}$ signaling. Cytosolic $\left[\mathrm{Ca}^{2+}\right]$ was monitored in Fluo-4 loaded cells with confocal microscopy, mitochondrial $\left[\mathrm{Ca}^{2+}\right]$ was recorded in Rhod-2 loaded cells with fluorescent wide-field microscopy. Each panel shows the response of 3 representative cells. The effect of 2-OHE was not statistically significant. 
Fig. 1
A H295R
HeLa



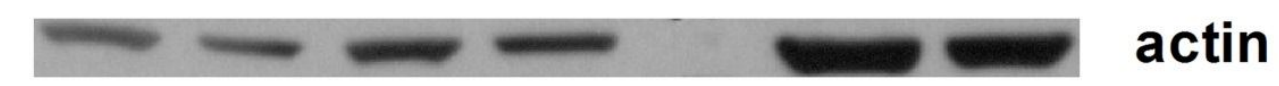

\section{B}
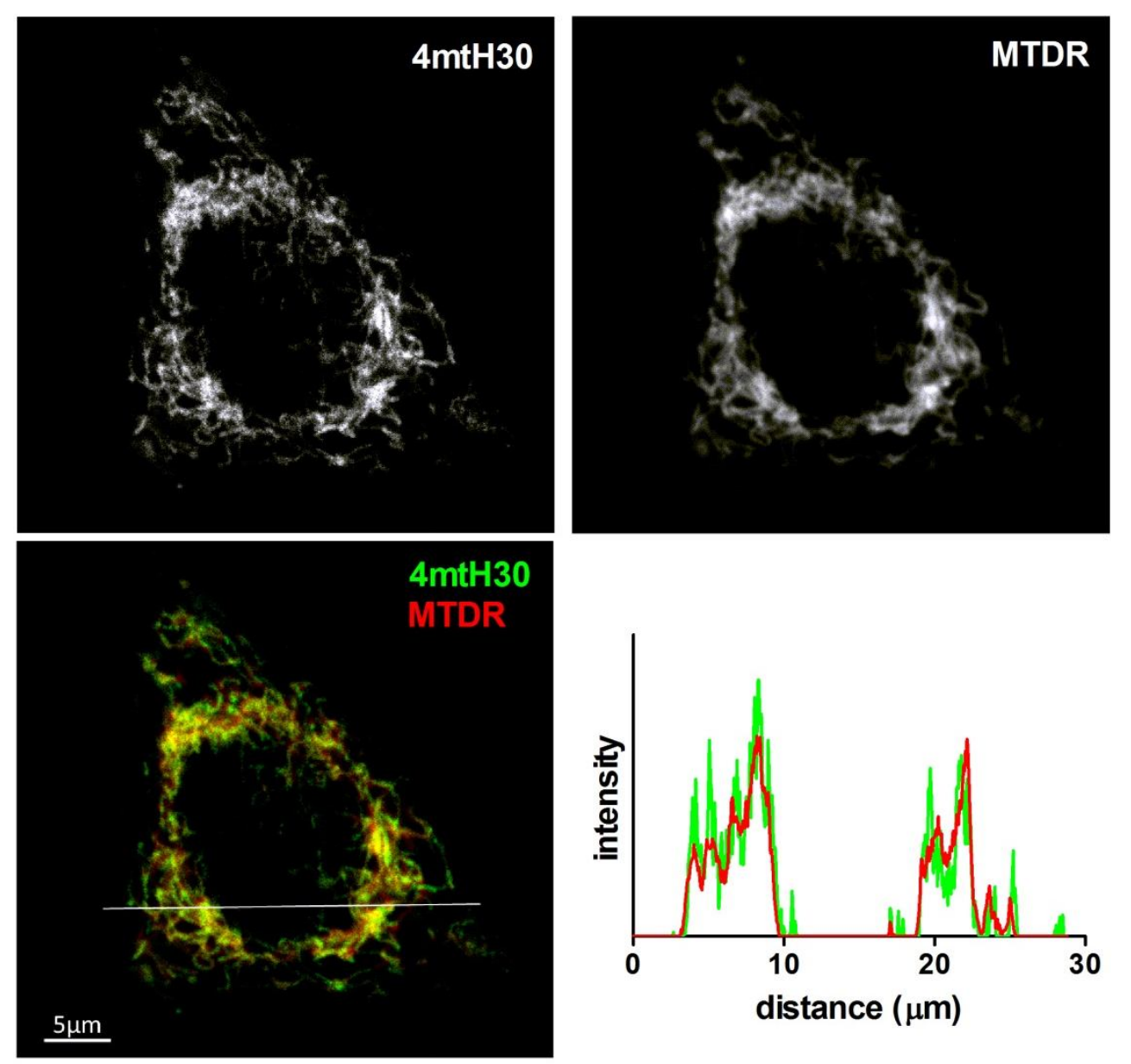
Fig. 2

A

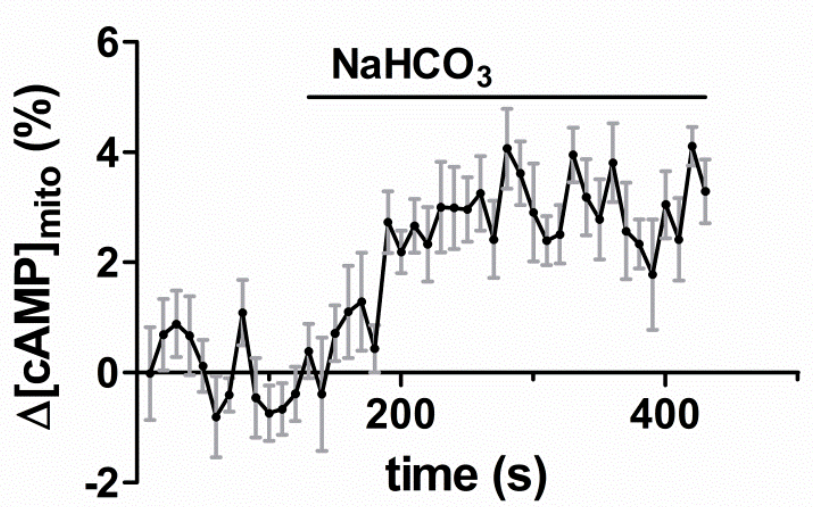

B

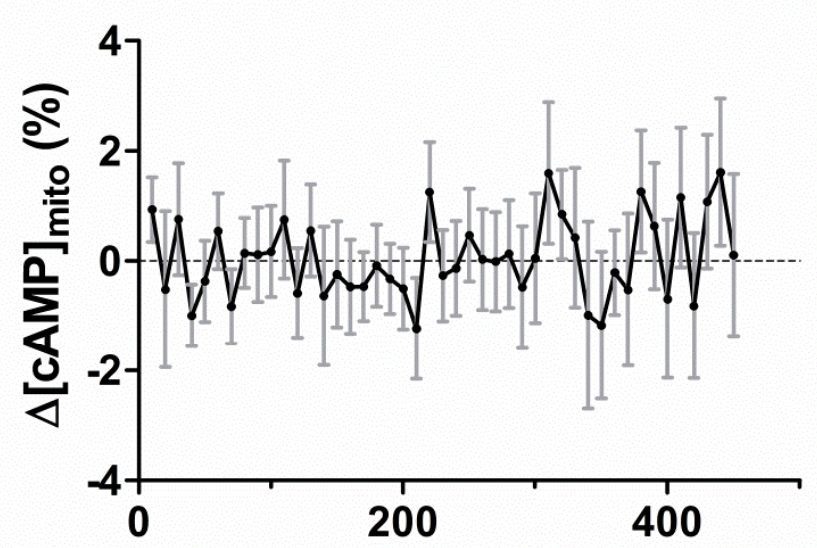

C




Fig. 3

A

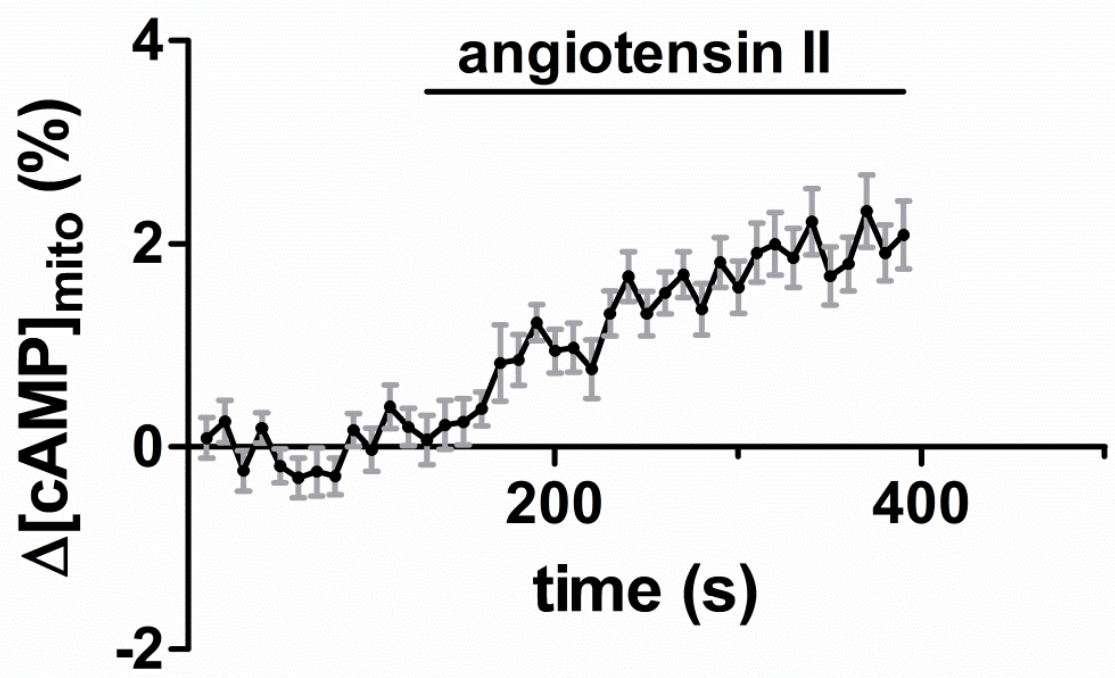

B

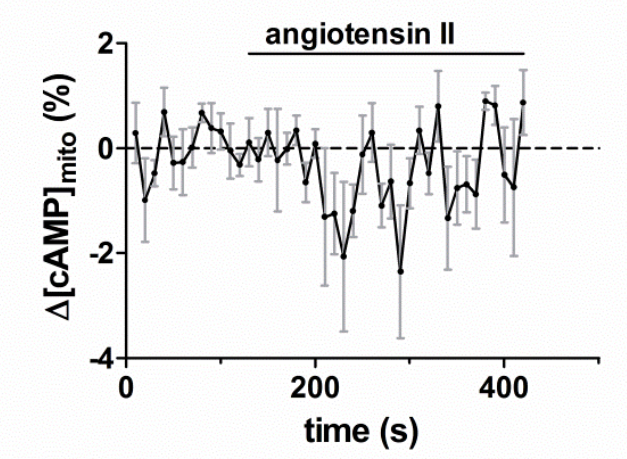

C

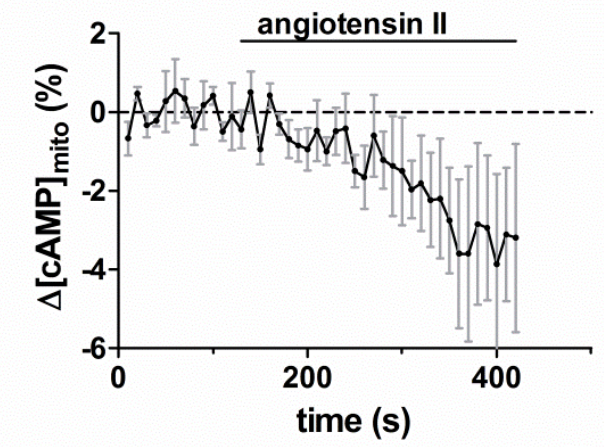


Fig. 4

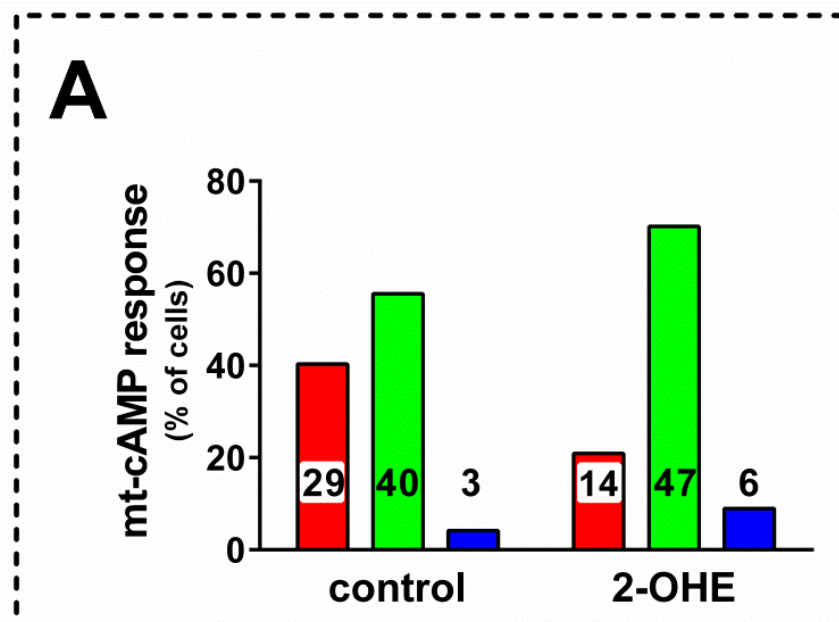

\section{B}

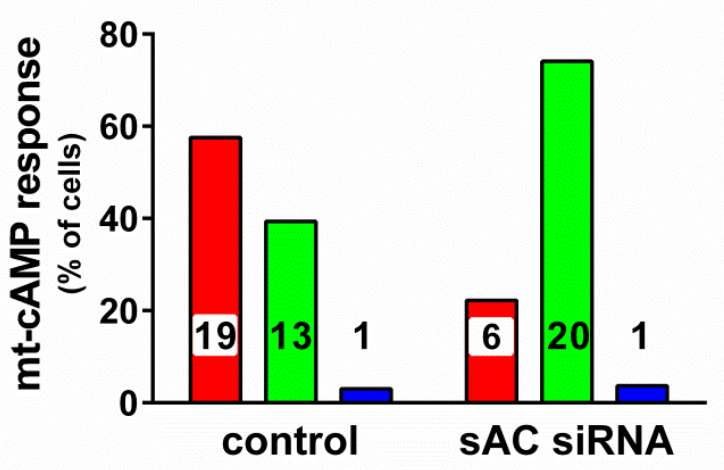

\section{$\square$ increase in cAMP $\square$ no response $\square$ decrease in cAMP}

\section{C}



D

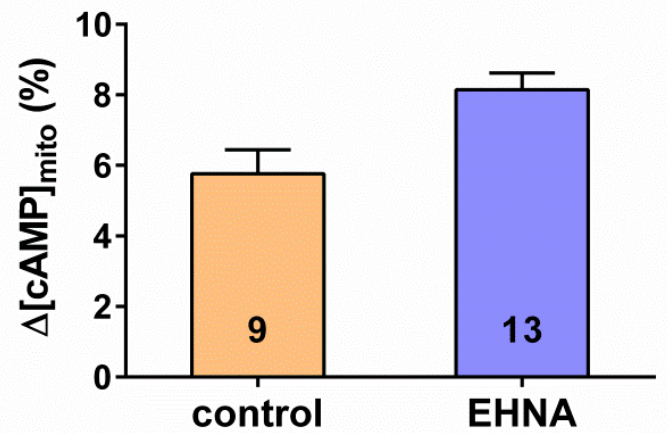


Fig. 5
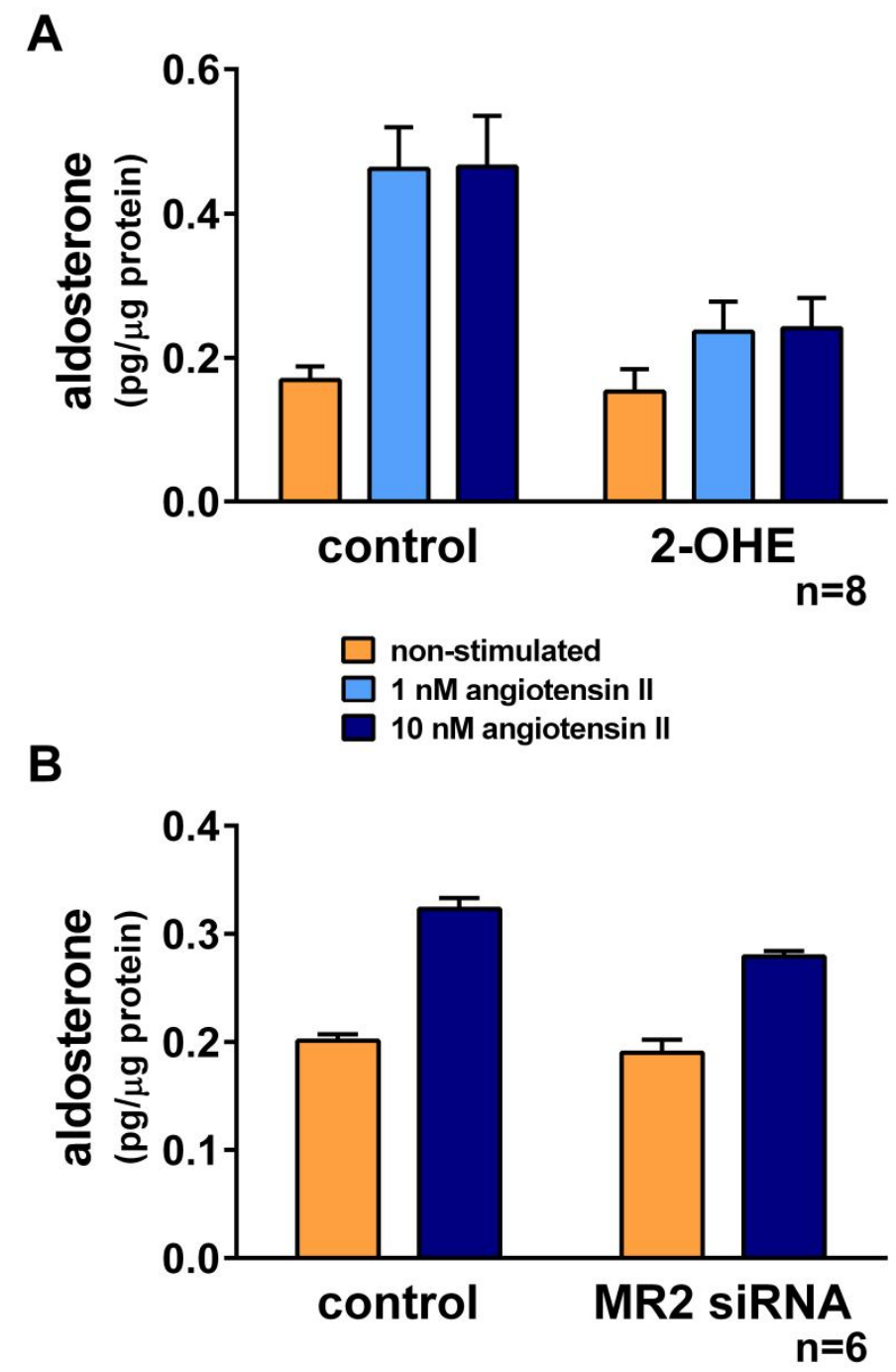
Fig. 6

A

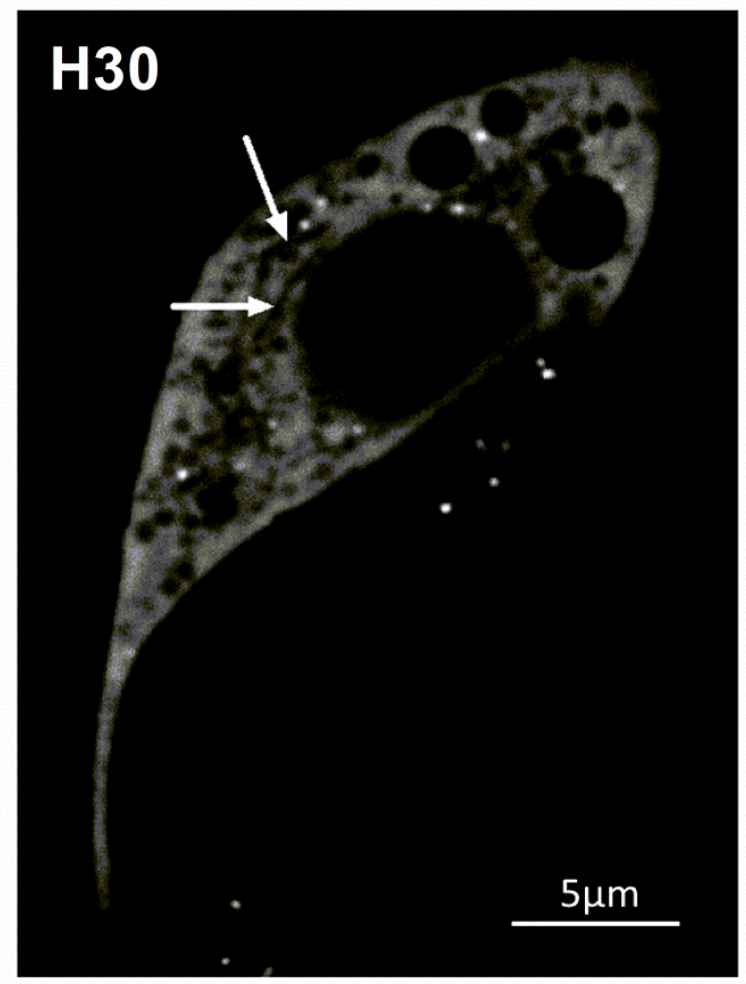

B

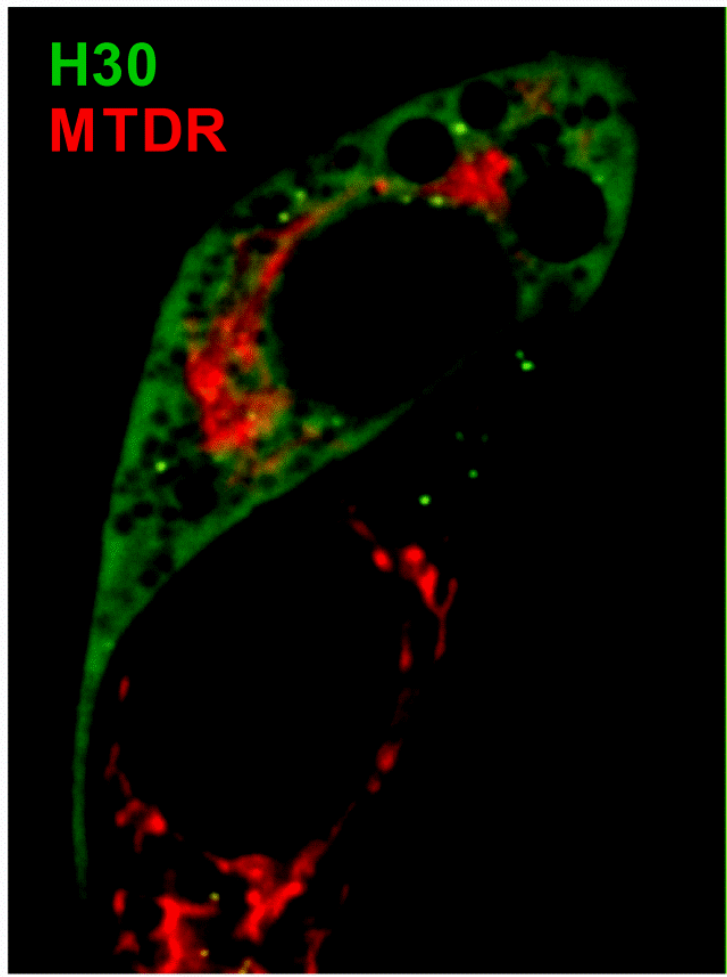

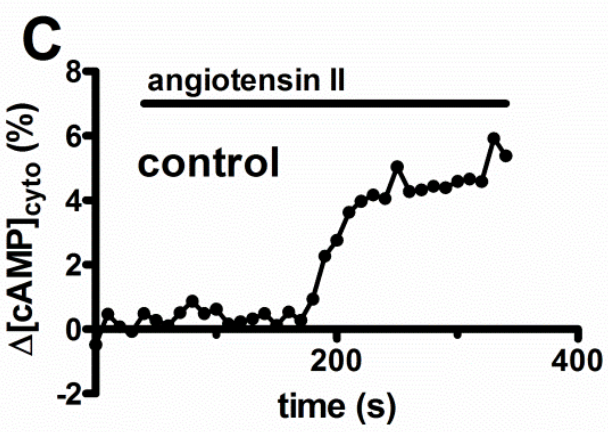

D
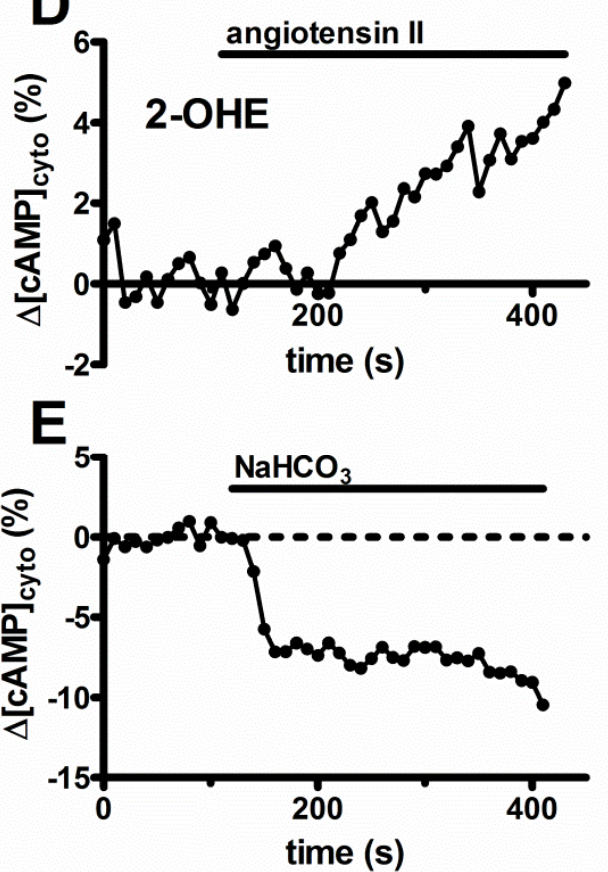
Suppl. Fig. 1

Suppl. Fig. 2
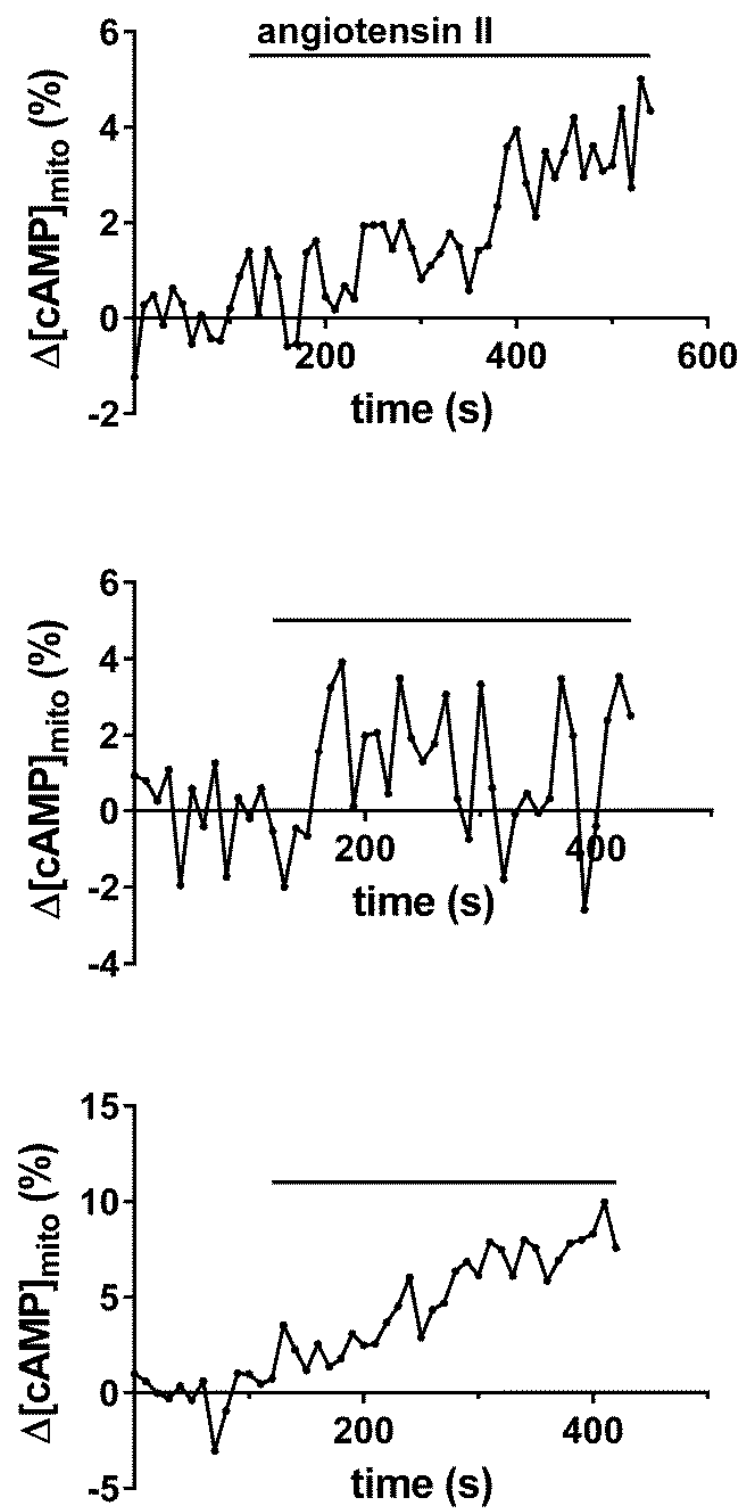


\section{control}
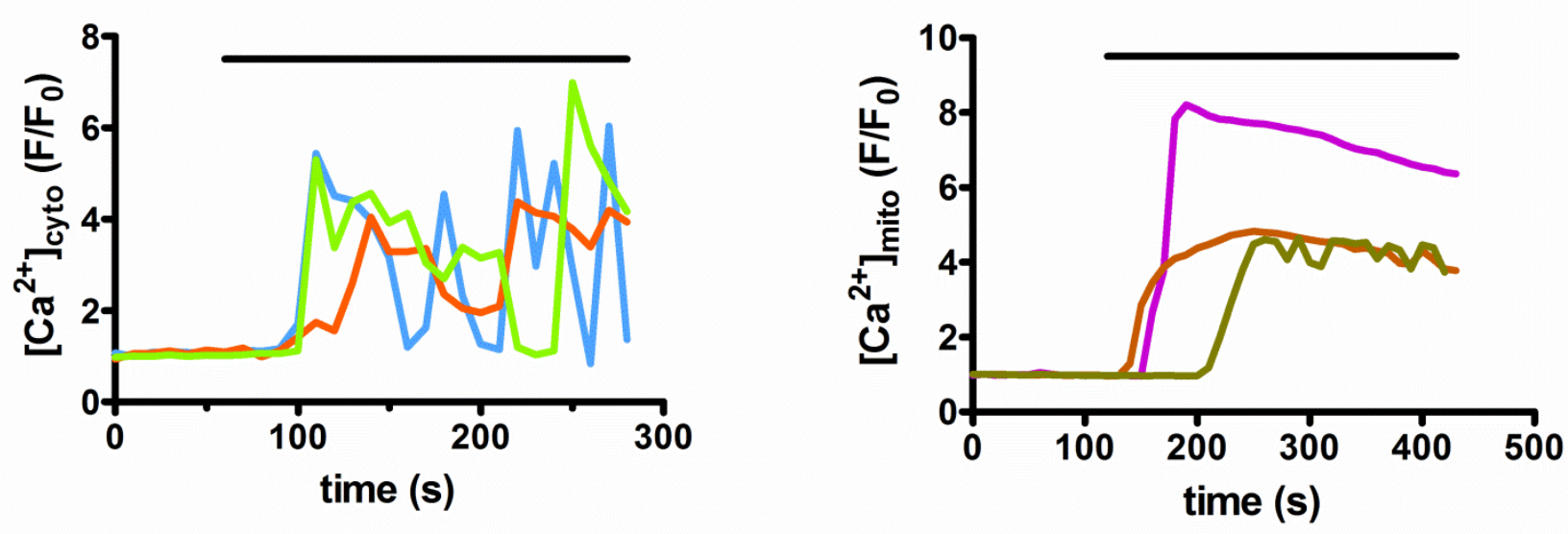

\section{2-OHE}
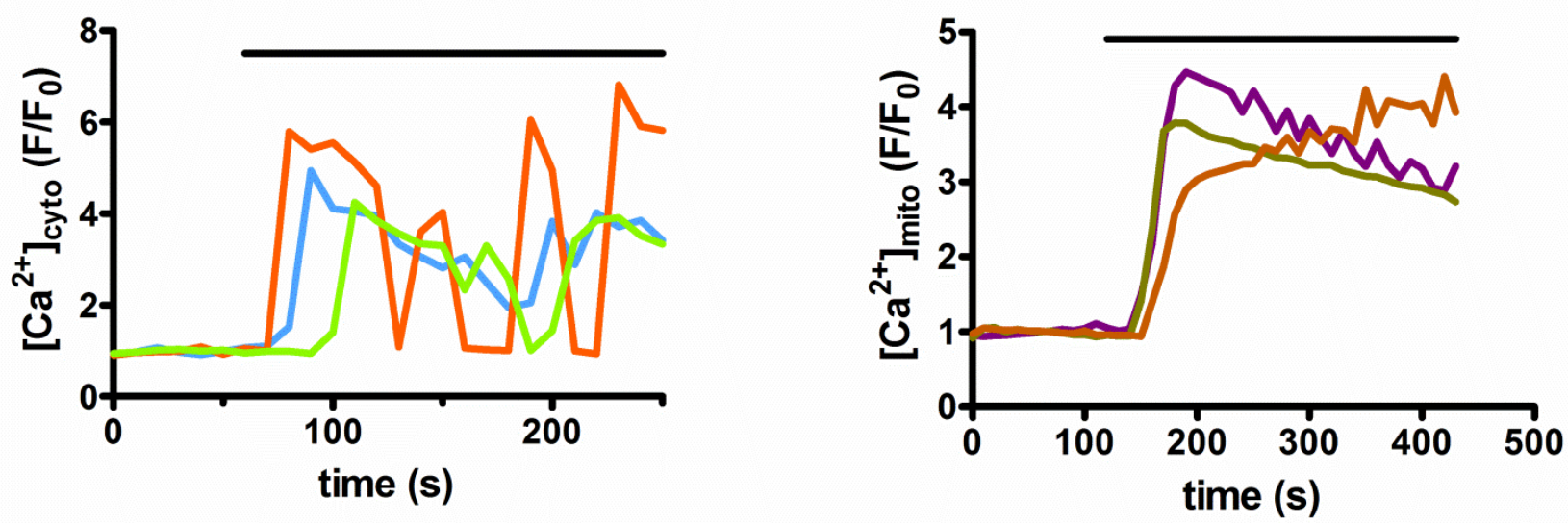


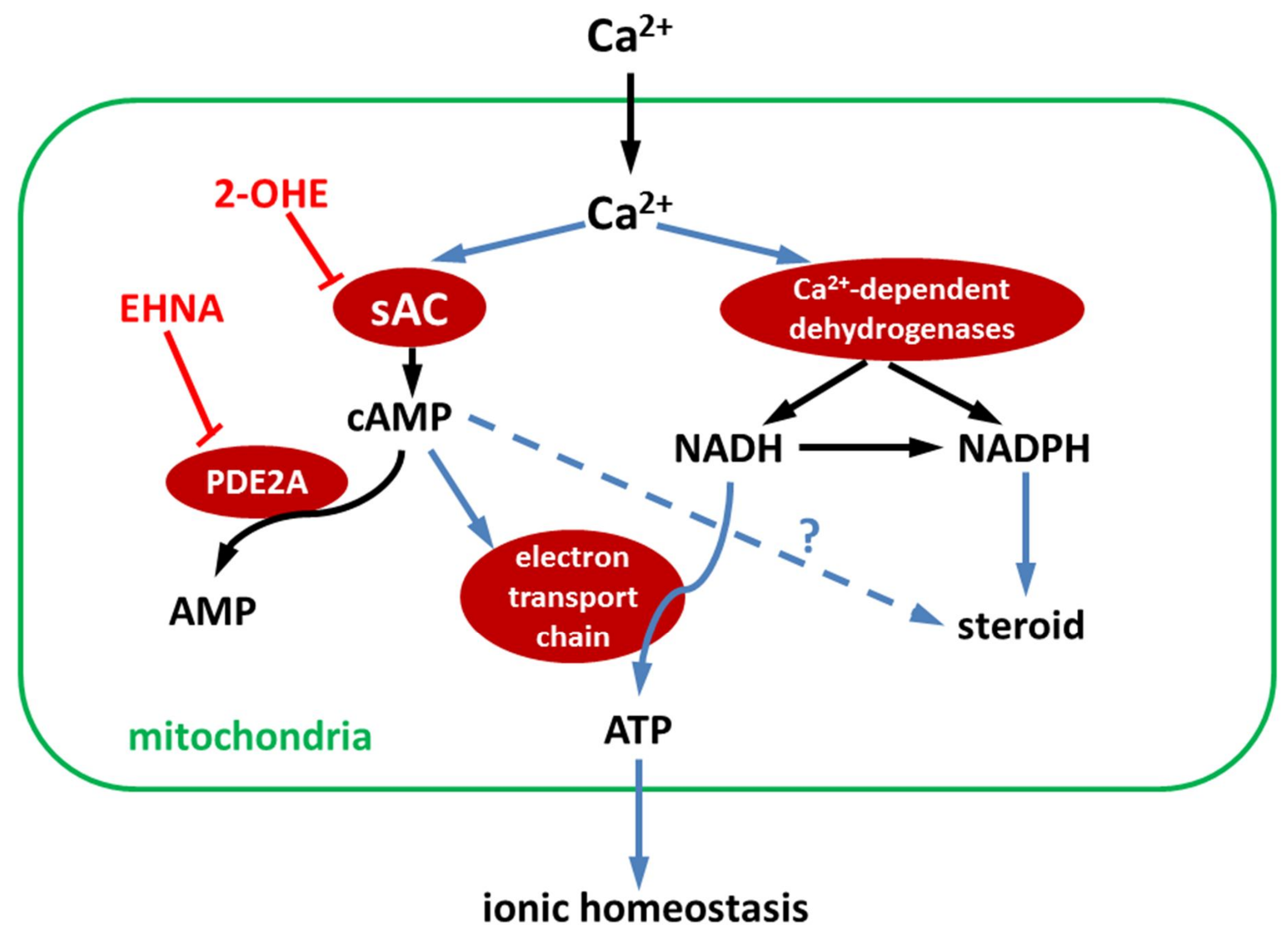

